\title{
Utilization of Digital Information Boards as Media Information in Rural Areas
}

\section{PKM pada Pra TK/TK Binakheir Sentul-Bogor (Pelatihan E- Commerce untuk Pemasaran Produk)}

\author{
Ahmad Suryadi*, Novrita Mulya Rosa, \& Reko Syarif Hidayatullah \\ Informatika, Universitas Indraprasta PGRI, Indonesia
}

\begin{abstract}
Information technology not only affects an information system, but also affects everyday life. These influences include lifestyles that begin to change along with the growth of information technology products. One of the information technologies applied in the marketing world is the application of popular e-commerce based marketing media. The problem found at Binakheir Kindergarten was that the income of teachers and staff was still insufficient to meet their daily needs. Referring to this matter, the enthusiasm in carrying out tasks was reduced. The next problem encountered was that teachers do not understand and do not have any skill in creating and managing an online store. This community service activity was carried out with the aim of increasing knowledge and improving teachers' skills in entrepreneurship and utilizing e-commerce as a medium for marketing the products they sell. The preparation stages applied in this activity consisted of partner surveys, licensing and material preparation. While the implementation stage of this activity included the socialization method of program introduction presentations, discussions and the practice of creating and managing an online store. The evaluation stage of this activity aimed to determine the ability of partners before and after the training. The results of this conducted activity indicated that there was an interest in entrepreneurship that arises from partners and an increase in partners' knowledge and skills in creating and managing online stores.
\end{abstract}

\begin{abstract}
Abstrak
Teknologi Informasi tidak hanya mempengaruhi sebuah system informasi, namun memiliki pengaruh dalam kehidupan sehari-hari, gaya hidup mulai berubah seiring dengan pertumbuhan produk-produk teknologi informasi yang semakon berkembang. Impementasi teknologi informasi dalam dunia pemasaran, salahsatunya melalui penerapan media pemasaran berbasis e-commerce popular. Permasalahan yang ditemukan di Pra TK / TK Binakheir yaitu penghasilan para guru dan staf yang belum cukup untuk memenuhi kebutuhan keseharian mereka. Hal ini menyebabkan berkurangnya semangat dalam menjalankan tugas. Permasalahan berikutnya adalah guru belum memahami dan memiliki ketrampilan dalam pembuatan dan pengoperasionalan toko online. Tujuan kegiatan pengabdian masyarakat ini adalah untuk menambah pengetahuan dan meningkatkan ketrampilan guru dalam berwirausaha dan memanfaatkan e-commerce sebagai media pemasaran produk yang mereka jual. Tahap persiapan terdiri dari survey ke mitra, perijinan dan penyiapan meteri Tahap pelaksanaan menggunakan metode sosialisasi presentasi pengenalan program, diskusi dan praktik pembuatan dan pengoperasionalan toko online. Tahap Evaluasi kegiatan bertujuan untuk mengetahui kemampuan mitra sebelum dan sesudah pelatihan. Hasil dari kegiatan adalah timbulnya minat berwirausaha dari mitra dan erjadinya peningkatan pengetahuan dan keterampilan mitra membuat dan mengelola toko online.
\end{abstract}

(C) 2020 Author(s)

Keywords: E-commerce, Online Shop.

\footnotetext{
* Corresponding author:

E-mail address: yadi2812@gmail.com (Ahmad Suryadi)
} 
https://doi.org/10.35877/454RI.abdiXXX

\section{Pendahuluan}

Teknologi Informasi tidak hanya mempengaruhi sebuah system informasi, namun memiliki pengaruh dalam kehidupan sehari-hari, untuk gaya hidup mulai berubah seiring dengan pertumbuhan produk-produk teknologi informasi yang semakon berkembang. Impementasi teknologi informasi dalam dunia pemasaran, salahsatunya melalui penerapan media pemasaran berbasis e-commerce popular. Melalui media tersebut memungkinkan akses informasi untuk promosi serta pemasaran yang dapat dilakukan seluas-luasnya tanpa terbatas ruang dan waktu (Fithri, Utomo, \& Nugraha, 2017). Diperkuat dengan pendapat (Awaludin, et.al., 2019) menyatakan bahwa Perkembangan teknologi dan komunikasi saat ini turut memberikan dampak positif juga dalam bidang kependidikan dan lingkungan. Media online adalah metode untuk memperkenalkan dan memasarkan suatu produk atau informasi seperti memberikan sebuah iklan. Saat ini media online merupkan hal yang sangat penting pada proses transaksi penjualan dan pengenalan produk untuk mendapatkan informasi dari produk yang ditawarkan. Salah satu media komunikasi yang dapat digunakan pelaku usaha untuk mempromosikan usahanya adalah komunikasi media maya atau media internet. Berdasarkan penelitian yang dilakukan oleh Irmawati (2011), menjelaskan bahwa penggunaan internet dalam dunia bisnis merupakan alat untuk pertukaran informasi secara elektronik menjadi alat aplikasi strategi bisnis. Pelaku usaha dapat memanfaatkan e-commerce dan marketplace yang memberikan peluang besar untuk memperkenalkan produk mereka secara luas melalui media digital. Marketplace adalah kegiatan menyediakan tempat kegiatan usaha berupa toko internet di mal internet sebagai tempat penjual online yang menjual produknya (Sakti, 2014). Saat ini untuk berhasil dalam berwirausaha, oarng-orang tidak harus lagi memiliki toko secara fisik. Hanya dengan bermodalkan toko online, tidak sedikit orang yang berhasil dalam menjalankan usahanya (Yulhendri \& Irawan, 2015). Dengan perkembangan internet yang pesat saat ini, setiap orang dapat memudah melakukan pembelian barang yang pemesanannya dilakukan.

Permasalahan yang ditemukan di Pra TK / TK Binakheir yaitu penghasilan para guru dan staf yang belum cukup untuk memenuhi kebutuhan keseharian mereka. Hal ini menyebabkan berkurangnya semangat dalam menjalankan tugas. Permasalahan berikutnya adalah guru belum memahami dan memiliki ketrampilan dalam pembuatan dan pengoperasionalan toko online.

Penumbuhan jiwa kewirausahaan mampu memberikan manfaat bagi masyarakat. Manfaat tersebut dapat berujud manfaat finansial maupun non finansial. Manfaat finansial dari kewirausahaan dapat berupa kemandirian ekonomi yang diperoleh dalam menjalankan usaha. Sedangkan manfaat non finansial berupa penumbuhan mental yang tangguh dan pantang menyerah dalam menghadapi permasalahan hidup.

Berdasarkan uraian yang telah dijelaskan sebelumnya, perlu diadakan pelatihan kewirausahaan bagi masyarakat khususnya kepada para guru dan staf untuk menumbuhkan jiwa kewirausahaan dan menggali potensi yang ada. Dengan diadakan pelatihan kewirausahaan diharapkan mampu memunculkan usaha baru. Kemampuan membuat toko online menjadi nilai tambah bagi setiap orang yang ingin memulai usaha tapi belum bisa memiliki toko secara fisik. Pengetahuan tentang digital marketing tidak hanya pada kajian promosi dan pemasaran saja, tetapi juga sudah mencakup pada penggunaan new media internet dalam proses komunikasi dan penjualan. Dengan adanya kegiatan ini diharapkan dapat membuka wawasan dan pengetahuan baru bagi para guru dan staf dan menjadikan mereka pengguna teknologi yang bisa memanfaatkan media internet secara bijaksana karena banyak hal yang bisa dimanfaatkan dan diketahui secara positif dari perkembangan internet khususnya pemasaran produk.

\section{Pelaksanaan dan Metode}

Tujuan kegiatan pengabdian masyarakat ini adalah untuk menambah pengetahuan dan meningkatkan ketrampilan guru dalam berwirausaha dan memanfaatkan e-commerce sebagai media pemasaran produk yang mereka jual. Kegiatan ini diharapkan dapat menumbuhkan jiwa kewirausahaan para guru dengan munculnya ide-ide kreatif dalam membuat produk yang mereka tawarkan dan mempromosikannya dengan media digital berbasis internet. Pada pelaksanaannya tahapan dan langkah-langkah kegiatan pengabdian masyarakat ini adalah sebagai berikut: 


\subsection{Tahap Persiapan}

Tim Abdimas melakukan survei ke wilayah mitra yaitu Pra TK / TK Binakheir. Pada kegiatan ini, tim melakukan pertemuan dengan Pimpinan lembaga dan bagian Humas. Pada pertemuan ini dilakukan diskusi identifikasi permasalahan mitra dan kebutuhan mitra serta perencanaan pelaksanaan kegiatan. Dari diskusi diharapkan tim abdimas bisa mengetahui kapan waktu yang tepat dan teknis pelaksanaann dalam melaksanakan kegiatan pengabdian masyarakat. Koordinasi Internal tim dilakukan untuk merencanakan pelaksanaan secara konseptual, operasional dan gambaran tugas masing-masing anggota.

\subsection{Tahap Pelaksanaan}

Metode yang digunakan dalam pelaksanaan kegiatan pengabdian masyarakat ini adalah sosialisasi dan pelatihan dengan melalui beberapa tahapan sebagai berikut:

a. Sosialisasi dan diskusi

Dalam kegiatan ini tim akan memaparkan kewirausahaan dan contoh ide-ide bisnis yang bisa diaplikasikan oleh mitra. Pada tahapan ini juga dipaparkan pemasaran produk menggunakan e-commerce. Selama pemaparan materi yang diselingi oleh diskusi atau bertanya jawab dengan peserta sehingga diharapkan terjadinya komunikasi timbal balik antara tim pengabdian dan peserta.

b. Pelatihan

Kegiatan dilanjutkan dengan pelatihan. Pelatihan yang dimaksud adalah praktek pembuatan dan penggunaan toko online untuk kegiatan usaha. Pelatihan tersebut berupa tutorial dan pendampingan praktek kepada mitra agar dapat membuat dan mengoperasikan toko online dalam kegiatan usaha. Adapun aplikasi yang dipraktekkan yaitu Shopee.

\subsection{Tahap Evaluasi/Pemantauan}

Evaluasi dilakukan untuk mengetahui respon mitra erhadap kegiatan pelatihan. Evaluasi juga dilakukan untuk mengetahui efektifitas kegiatan Pengabdian Masyarakat bagi peningkatan pengetahuan dan ketrampilan mitra dalam menggunakan aplikasi e-commerce untuk kegiatan usaha.

\section{Hasil dan Pembahasan}

Program pengabdian masyarakat mulai dari perencanaan hingga pengumpulan laporan akhir berlangsung pada periode bulan April 2020 hingga Juli 2020. Kegiatan ini bertujuan untuk meningkatkan pengetahuan dan keterampilan guru dalam menbuat toko online dan mengoperasikan toko online untuk memasarkan produk yang mereka tawarkan. Kegiatan Pengabdian Masyarakat ini telah terlaksana dengan baik berkat dukungan berbagai faktor yaitu komunikasi antar anggota tim berlangsung lancar dan efektif sehingga koordinasi tim pada proses persiapan, pembagian tugas, pelatihan dan simulasi dapat berlangsung dengan baik dan tepat waktu. Peserta pelatihan terdiri dari guru dan staf Pra TK / TK Binakheir. Peserta sangat antusias dan bersemangat mengikuti pelatihan.

Hasil pengamatan selama kegiatan, guru dan staf bersemangat dalam mengikuti sosialisasi kewirausahaan dan pemasaran online dengan aplikasi toko online. Dari kegiatan ini, banyak bermunculan ide dari peserta untuk berwirausaha. Diantaranya terdapat peserta yang ingin menjual produk berupa makanan karena memiliki keahlian dalam memasak. .Terdapat pula peserta yang ingin memasarkan produk berupa barang kerajinan dari limbah rumah tangga. Terdapat pula peserta yang ingin memasarkan barang berupa tas dan sepatu kulit yang didapat dari kerabatnya seorang pengrajin pembuat produk dari kulit namun memiliki keterbatasan dalam hal pemasaran produknya.

Peserta antusias mengikuti kegiatan sosialisasi dan pelatihan dari awal hingga akhir. Pelatihan berlangsung menarik karena terjadi interaksi dua arah antara pemateri dan peserta. Peserta diberikan pendampingan dan pengarahan agar materi yang diberikan dapat dipahami dan dipraktekkan dengan baik. Tim Abdimas mengikutsertakan dua mahasiswa untuk berpartisipasi sebagai trainer dalam pelatihan. 
Materi yang pertama tentang kewirausahaan bagi pemula. Pada sesi ini, tim menyampaikan bahwa setiap orang bisa berwirausaha sesuai dengan minat dan bakat yang mereka miliki. Sesuai dengan inti dari jiwa kewirausahaan yaitu kemampuan untuk menciptakan sesuatu yang baru dan berbeda melalui berfikir kreatif dan bertindak inovatif untuk menciptakan peluang dalam menghadapi tantangan hidup, maka seorang wirausaha harus mempunyai kemampuan kreatif dalam mengembangkan ide dan pikirannya (Isbanah, Kautsar, \& Prabowo, 2017).

Materi berikutnya tentang pemasaran online. Pemasaran online merupakan strategi pelaku usaha dalam memasarkan produknya. Mengingat pada jaman sekarang perdagangan dilakukan secara online dengan memanfaatkan media smartphone maupun computer dengan tujuan menjangkau pasar lebih luas. Selain itu, perdagangan online juga memudahkan pembeli dalam bertransaksi dan mendapatkan barang sehingga saat ini perdagangan online lebih diminati masyarakat daripada berbelanja ke toko. Pemateri memperkealkan beberapa macam market place sebagai toko online yang banyak digunakan pelaku usaha di Indonesia.

Selanjutnya dilakukan pelatihan berupa praktek pembuatan akun market place sebagai media pemasaran online. Pada kegiatan pengabdian masyarakat ini, tim memberikan pelatiahn pembuatan dan pengelolaan akun toko online shopee. Shopee merupakan akun market place untuk kegiatan perdagangan dengan mekanisme rekening bersama. Dana yang ditransfer pembeli atas pembelian suatu barang masuk pada rekening bersama shopee dan ditahan sampai barang diterima pembeli dalm keadaan aman, sehingga ketika barang sudah diterima dengan aman oleh pembeli maka shopee akan melepas dana ke rekening penjual. Mekanisme tersebut bertujuan untuk menghindari adanya penipuan karena jika barang yang dikirim tidak sesuai maka pembeli dapat mengajukan pengembalian dana.

Pelatihan dilakukan melalui praktek secara langsung oleh masing-masing peserta dengan media smartphone. Pelatihan diawali dengan pembuatan akun, kemudian cara menggunakan fitur-fitur dalam akun, unggah produk hingga cara transfer dan cara pengiriman barang.beberapa peserta telah siap dengan foto produk yang akan diunggah ke akun dan beberapa masih belum mengunggah dikarenakan belum menyiapkan foto produk dan terdapat pula yang belum memiliki ide produk apa yang akan dipasarkan. Produk yang telah diunggah diantaranya souvenir, kerajinan kulit berupa tas, jaket, sepatu, dan makanan. Evaluasi kegiatan untuk melengkapi informasi yang belum dipahami oleh peserta. Dampak yang terlihat secara langsung pada saat kegiatan berlangsung adalah minat dan antusiasme peserta yang besar dalam mengikuti kegiatan, mulai dari perkenalan, penyampaian materi, tanya jawab, hingga mempraktikkan pembuatan akun shopee.

Secara keseluruhan produk dari kegiatan ini adalah meningkatkan pengetahuan mitra mengenai kewirausahaan dan pemanfaatan toko online untuk memasarkan produk dagangan mereka. Peserta mampu membuat akun toko online, menggunakan fitur-fiturnya dan mengelola toko online nya.

Hasil kegiatan ini sejalan dengan pengabdian masyarakat yang dilakukan oleh Rachman \& Ramdani (2016) yang menyimpulkan bahwa pelatiahan penggunaan aplikasi e-commerce berbasis web yang telah dilaksanakan dapat memberikan kemampuan dalam mengorganisisr pesanan konsumen serta dapat memudahkan pengguna untuk menampilkan status setiap barang dalam transaksi online dengan mengaplikasikan dalam kegiatan pelatihan. Kegiatan pengabdian yang sama juga dilakukan oleh Evasari, et.al. (2019) yang berjudul Pelatihan dan pemanfaatan ecommerce sebagai media pemasaran produk UMKM di desa Tales Kecamatan Ngadiluwih, Kabupaten Kediri. Dari hasil kegiatan tersebut diperoleh bahwa dengan adanya bantuan pelatihan aplikasi e-commerce dapat meningkatkan motivasi bagi mitra untuk melaksanakan pemasaran terhadap produknya. Kegiatan serupa juga dilaksanakan oleh Haris, Yudhitia dan Dian (2019) dengan judul kegiatan Sosialisasi \& Pelatihan E-Commerce Beserta Aspek Hukumnya bagi pelaku usaha Rumah Payet Sulam Kecamatan Genuk Kota Semarang. Hasil kegiatannya peserta antusias dalam membuat akun shopee sebagai toko online untuk memasarkan produknya.

Dari kegiatan yang telah berlangsung diharapkan mitra dapat menjalankan usahanya dan memasarkan produknya di toko online secara berkelanjutan. Perlu adanya semangat dan daya juang yang tinggi dari mitra agar dapat berhasil menjadi wirausaha dengan demikian dapat menambah penghasilan untuk memenuhi kebutuhan hidup. Kerjasama tim dengan mitra diharapkan akan berlanjut dengan memberikan pelatihan terkait dengan bagaimana meningkatkan kualitas produk yang ditawarkan agar mampu bersaing dengan produk-produk sejenis. 


\section{Kesimpulan}

Kegiatan sosialisasi kewirausahaan telah menumbuhkan jiwa kewirausahaan mitra. Peningkatan pengetahuan mitra terhadap pemasaran produk dengan menggunakan e-commerce berupa toko online. Mitra memiliki kemampuan membuat toko online dan menggunakan fitur-fiturnya. Kegiatan pelatihan dan pendampingan hendaknya dilakukan secara kontinu, sehingga dapat diketahui kendala apa yang dialami mitra selama mengelola toko online. Tim dapat melaksanakan kegiatan yang sama dengan jumlah peserta yang lebih banyak dan waktu yang memadai.

\section{References}

Awaludin, A. A. R., Hartuti, P. M., \& Rahadyan, A. (2019). Aplikasi Cabri 3D Berbantu Camtasia Studio untuk Pembelajaran Matematika di SMP. E-Dimas: Jurnal Pengabdian kepada Masyarakat, 10(1), 68-75.

Evasari, A. D., Utomo, Y. B., \& Ambarwati, D. (2019). Pelatihan Dan Pemanfaatan E-Commerce Sebagai Media Pemasaran Produk UMKM Di Desa Tales Kecamatan Ngadiluwih Kabupaten Kediri. Cendekia: Jurnal Pengabdian Masyarakat, 1(2), 75-84.

Fithri, D. L., Utomo, A. P., \& Nugraha, F. (2017). Pemanfaatan E-Commerce Populer Populer untuk Optimalisasi Pemasaran Produk pada Kube Bordir Kurnia Desa Demangan Kudus. Simetris: Jurnal Teknik Mesin, Elektro dan Ilmu Komputer, 8(2), 819-824.

Haris, M., Yudhitiya, D.S., Dian, I.T.L. (2019). Sosialisasi \& Pelatihan E-Commerce beserta aspek hukumnya bagi pelaku usaha rumah Payet Sulam Kecamatan Genuk Kota Semarang. Thesis. Manajemen Fakultas Ekonomi Universitas Semarang.

Irmawati, D. (2011). Pemanfaatan e-commerce dalam dunia bisnis. Jurnal Ilmiah Orasi Bisnis.

Isbanah, Y., Kautsar, A., \& Prabowo, P. S. (2017). Membangun Kemandirian Financial Anak Panti Asuhan Melalui Pelatihan Kewirausahaan. Jurnal Abdimas, 21(2), 153-160.

Rachman, A. N., \& Ramdani, C. M. S. (2016). IbM Pelatihan Pemanfaatan E-Commerce Sebagai Media Pemasaran Global Untuk Peningkatan Penjualan Produk Kelom Geulis (Studi Kasus: UKM kelom geulis Tamansari Tasikmalaya). Jurnal Pengabdian Siliwangi, 2(1).

Sakti, N. W.. (2014). Buku Pintar Pajak E-Commerce. VisiMedia.

Yulhendri, Y. \& Irawan, B. (2015). Pelatihan E-Commerce dengan membuat toko online menggunakan opencart di SMK Pasundan Tangerang. Jurnal Pengabdian Masyarakat. 2(1), 110-118. 